\title{
濃厚粒子分散系の流動反転時における壁面近傍粒子の特異挙動 Anomalous behavior of dispersed particles near the wall surface after flow reversal of concentrated suspension
}

○学 五十嵐 文弥（新潟大院自） 正 鳴海 敬倫（新潟大工） 正 牛田 晃臣（新潟大工）

Fumiya IGARASHI, Graduate School of Niigata University, 8050, 2-no-chou, Ikarashi, Nishi Ward, Niigata

Takatsune NARUMI, Faculty of Engineering Niigata University, 8050, 2-no-chou, Ikarashi, Niigata

Akiomi USHIDA, Faculty of Engineering Niigata University, 8050, 2-no-chou, Ikarashi, Niigata

Key Words: Complex Fluid, Concentrated Suspension, Transient Response, Particulate Microstructure

\section{1. 緒言}

工業上で扱われる粒子分散系は多様で，塗料，充填剤を 含むプラスチック融液, 食品など様々な系が存在する。し かし，それらの粒子の流動構造は複雑であり，不明な点も 多い.例えば,流体に粒子を高体積分率で分散させた系は, 流動反転時に粒子の流動構造に起因する過渡応答が生じる。 これまで, この過渡応答について, 球形粒子をニュートン 流体・粘弾性流体に高体積分率で分散させた系の過渡挙動 について, 大振幅を伴う振動流（LAOS 流動） ${ }^{1)}$, 流動反転 を伴う加速流動 2) 用いて, マクロ的な流動特性の変化の 観点から検討されてきた。しかしながら, この過渡挙動中 の粒子の具体的な流動構造の変化については明らかにされ ていない.

そこで，本研究では，流動反転時の粒子の具体的な流動 構造の変化について検討する目的で, 分散媒がニュートン 流体の比較的単純な濃厚粒子分散系にトレーサーとして黒 色単分散粒子を混合した系に対して流動反転実験を行い, その時のトレーサー粒子の挙動を観察した。具体的には, 試験流体に予せん断として一定せん断流動を印加した後に, 流動を静止させ，その後に予せん断の向きに対して同方向 または逆方向に再度一定せん断を加え, 再せん断の方向を 変化させた場合の, 主に壁面近傍の粒子の挙動を比較し検 討を行った。

\section{2. 試験流体}

本実験では, Liquid Paraffin (比重 0.86, 和光純薬工業(株), 以下 LP) に Polybutene (比重 0.89 , 新日本石油(株), 以下 PB) を 46wt\%溶解した溶液を分散媒として使用した。この濃度 は，後述の分散粒子と屈折率が同程度となるように調節し た結果である。なお，この液体はニュートン流体である。 分散粒子には，粒子径分布が広い多分散粒子であるアクリ ル樹脂製球形粒子 MA1010 (比重 1.2 , 平均粒径 $\mathrm{d}=10.2 \mu \mathrm{m}$, 粒子径分布標準偏差 $\sigma=3.79 \mu \mathrm{m}$, 日本触媒(侏) を用い, 粒子 体積分率 $\Phi=0.50$ で上記の分散媒に分散させた.この濃厚 粒子分散系は分散媒と分散粒子の屈折率が近いため光をよ く透過する. そこにトレーサー粒子として，粒子径分布の 極めて狭い単分散粒子で, 黒色に染色されたメラミン樹脂 製球形粒子 GP-HC110（比重 $1.4, \mathrm{~d}=10 \mu \mathrm{m}, \sigma=0.35 \mu \mathrm{m}$, 日 本触媒(株)製）を全体の体積分率に影響しないよう微量 $\left(\Phi \leqq 5 \times 10^{-4}\right)$ 分散させた系を試験流体として用いた。

\section{3. 実験装置と実験方法}

本実験では，顕微鏡（Olympus 社, BX60）に取り付けら れたひずみ制御型せん断流動観察ユニット（Linkam Scientific Instruments 社, CSS450) とデジタルカメラ （NIKON 社, COOLPIX P5000）を用いて流動時におけるト
レーサー粒子の挙動を 30fps で撮影し, 動画解析ソフトに よってトレーサー粒子の 1 フレームごとの速度を算出する ことで評価を行った．試料は Fig.1 に示すように， 2 枚の ガラス円板のすき間 $(h=100 \mu \mathrm{m})$ に設置し，予せん断を定 常状態になるのに十分な時間かけ，その後，10s 間流動を 静止させた，続いて，予せん断の向きに対して，同じ方向 （順方向）または逆の方向（反転方向）に一定のせん断速 度で流動 (再せん断) を加えた. 再せん断時のせん断速度 $\dot{\gamma}$

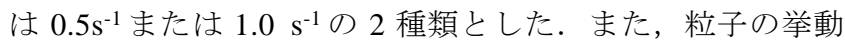
は二円板間の高さ方向の位置によって異なる可能性がある ため, Fig.1の様に上部ガラス円板下面につけたマーカーに ピントを合わせることにより，原点を定め，そこから下向 きに $\mathrm{z}$ 軸を定義した。原点に対して相対的に対物レンズを 下ろすことで観察位置 $z$ を変えて撮影を行った。しかしな がら $z=50 \mu \mathrm{m}$ 以降については, 光の屈折や散乱による影響 が大きく, 鮮明な粒子像が観察できなかったため, 観察面 の位置 $z$ は 0 50 $\mu \mathrm{m}$ とした。

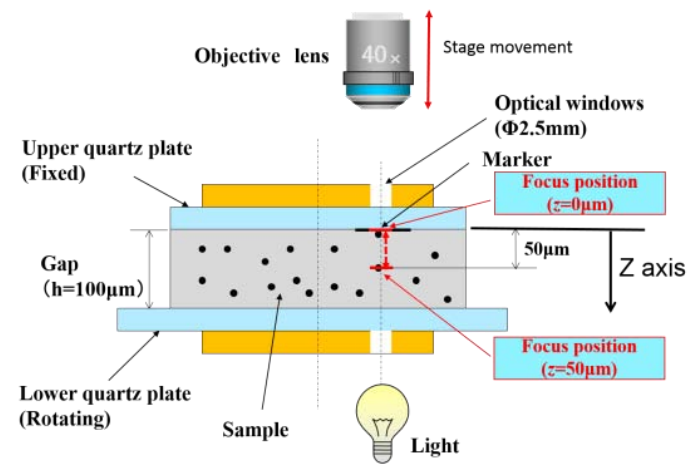

Fig.1 Main part of experimental apparatus

\section{4. 実験結果および考察}

まず，定常状態において測定された gap $(z)$ 方向に対す る粒子の速度分布を Fig.2 に示す. 図の横軸はピント位置 $z$ をガラス円板のすき間 $h$ で除して基準化した值である. マーク（○）は測定された粒子の速度の平均值を, 直線は 理想的なクエット流れの場合の速度分布を示している。な お， $z / h=0.05(z=5 \mu \mathrm{m})$ のデータは，ピント位置をガラス 下面に合わせた場合の結果であるが，粒子の中心位置の值 として示している.グラフからおおよそ $z / h \leqq 0.2$ 以下の領 域では, 理想的なクエット流れの場合に比べ全体的に高く なっており, 特に静止壁面においても速度は 0 にならない ことがわかる。透明粒子も含め動画を詳細に検討したが， 壁面近傍で静止している粒子は観察されなかったことから， 静止壁面で粒子が滑っていると考えられる。続いて, 運動 再開時の粒子の過渡的な速度変化について述べる. Fig.3 
に代表例として $\dot{\gamma}=1.0 \mathrm{~s}^{-1}, z=10 \mu \mathrm{m}$ の場合の再せん断(反 転方向）開始時の粒子速度 $V$ の時間変化を青いラインで示 す. 図から粒子の速度は常に変動していることが分かる. これは $z$ 方向に隣接する速度の違う密な粒子群に対し相対 的に移動する際に. 左右上下の微動と速度変動が生じるこ とに起因していると考えられる．実際に左右方向の微変動 も測定されている.また, Fig.3では粒子の速度は徐々に増 加していき, 数秒後におおよその定常值となっていること が分かる．ここでは示さないが，再せん断の方向が順方向 の場合は粒子の速度は急速に上昇して定常值に至っていた. この様に, 流動反転時の速度の増加の遅れる傾向（以下, 過渡挙動とす呼ぶ）は再せん断が反転方向の場合でのみ特 徵的な傾向であると考えられることから，本報ではこの過 渡挙動を中心に検討を行った. 過渡挙動について定量的に 評価するために, 粒子速度 $v$ が概ね定常值となるまでの時 間 $t_{e}$ を代表量として導出した. Fig.3のように粒子の速度 変化（青）に対して大まかに近似線（赤）を引き，その近 似線において概ね一定值となるまでの時間を $t_{e}$ として定義

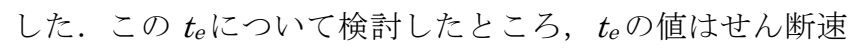
度に依存し, $\dot{\gamma}=0.5 \mathrm{~s}^{-1}$ の場合で $\dot{\gamma}=1.0 \mathrm{~s}^{-1}$ の場合に比べて 2 倍程度となった. すなわち, 過渡挙動が終了するタイミ ングは $t_{e}$ と $\dot{\gamma}$ 積で見積もられるひずみ量で整理できると 予想される. そこで, それらの積で定義した, 過渡挙動が 終了するまでのひずみ量 $\gamma_{e}$ を用いて検討した.この $\gamma_{e}$ と $z / h$, $\dot{\gamma}$ の関係について整理した結果を Fig.4 に示す. 図より,

再せん断が反転方向の場合で, 静止壁面近傍の粒子の速度 の増加が遅れており, 遅れが見られる範囲は最大で, おお よそ $z / h=0.4$ 程度となっている. $\gamma_{e}$ の代表值として静止壁面 に一番近い $z / h=0.05$ での值を考えると，おおよそ $2-3$ 程度 となっている. 従来の全体量としての過渡応答に関寸る研 究においても, その過渡応答が終了するタイミングはひず み量で整理できることが分かっており，今回用いた分散系 と条件が近い系の場合の過渡応答が終了するひずみ量は 2.5-3.0 程度 ${ }^{2)}$ であった. このように, 粒子の過渡挙動は全 体量の過渡応答とはある程度対応していると言え, どちら も流動反転時の異方性構造の変化に起因するものと推測さ れる.今回の実験では運動面側の粒子の挙動を確認できて いないが, 静止面側の粒子の挙動に方向依存性があること から，予せん断流動で静止面近傍の粒子が形成する構造に 異方性があることは自明である。順方向に回転を再開する 場合には静止状態から図 2 に示すような壁面での滑りを伴 う状態に，非常に少ない変形で復帰することになる。この 図 2 の速度分布ではクエット流れの状態よりも壁面での応 力が高くなることが予想される。一方で, 逆方向に流動を 再開する場合には，予せん断で形成された構造が一旦崩壊 するため, 図 3 のような粒子の動きの遅れが生じると考え られる。その間, 壁面近傍では, 図 2 に示寸速度より遅い 運動をしており, 壁面に伝わる応力は低いと考えられる. すなわち，見かけ上の粘度が下がることになる．全体量で 測定した過渡応答は, 装置が応力制御型であったため, 直 接的な比較はできないが，こちらも見かけ上の粘度が下が る現象であることは同じであり，本実験結果と対応すると 考えられる。運動面近傍でも同様な挙動が生じていると考 えられるが，今後正確に検証する必要がある。

\section{5. 結言}

本研究において，ひずみ制御方式で，予せん断を加えた 後に再せん断を加える実験を行った結果, 再せん断で反転 させる場合には順方向の場合に比べ，壁面近傍粒子の速度 の増加が遅れる特異な挙動が観察された。この現象は全体 量の過渡応答と同様に流動反転時の異方性構造の変化によ って生じていると考えられる. 詳細なメカニズムについて はさらに検討が必要であるが, 流動方向の反転によって局 所的な粒子の挙動に変化が生じたことは非常に興味深い.

\section{参考文献}

（1）吉田 鮎美,鳴海 敬倫, “粘弾性濃厚サスペンションの大 振幅振動せん断流大振幅振動せん断流における流動反転時 の過渡応答”, 日本レオロジー学会誌 Vol.39 No.4, 173-180 (2011)

(2)吉田 鮎美, “粒子分散系粘弾性流体の非定常流動化での 過渡応答” 修士論文, 新潟大学大学院(2012)

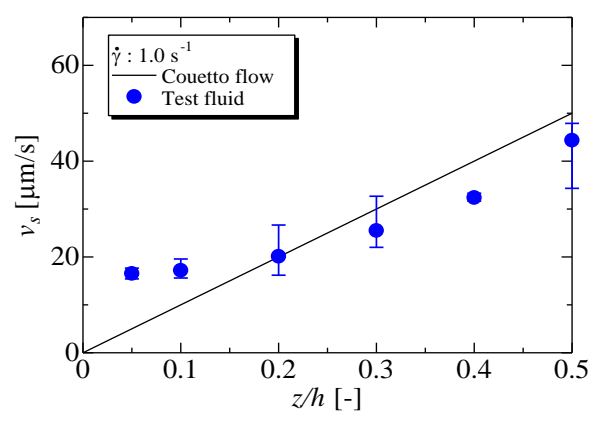

Fig.2 Velocity distribution near the stationary wall measured in the case of $\dot{\gamma}=1.0 \mathrm{~s}^{-1}$

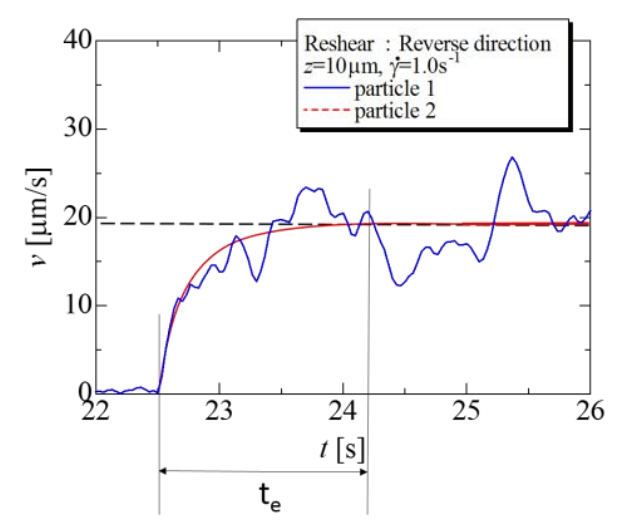

Fig.3 Particle velocity growth after shear reversal at $z=10 \mu \mathrm{m}$ in the case of $\dot{\gamma}=1.0 \mathrm{~s}^{-1}$

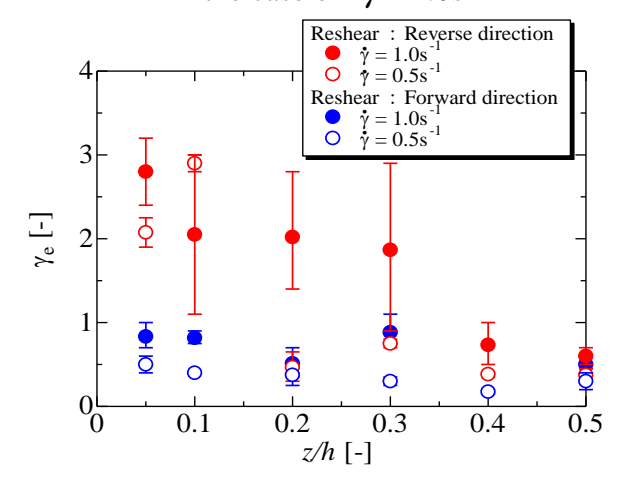

Fig.4 Influence of shear direction on characteristic strain $\dot{\gamma}_{e}$ corresponding to velocity growth 